\title{
Effectiveness of alcohol-based hand disinfectants in a public administration: Impact on health and work performance related to acute respiratory symptoms and diarrhoea
}

\author{
Nils-Olaf Hübner ${ }^{1 *}$, Claudia Hübner ${ }^{1}$, Michael Wodny², Günter Kampf ${ }^{3}$, Axel Kramer $^{1}$
}

\begin{abstract}
Background: The economical impact of absenteeism and reduced productivity due to acute infectious respiratory and gastrointestinal disease is normally not in the focus of surveillance systems and may therefore be underestimated. However, large community studies in Europe and USA have shown that communicable diseases have a great impact on morbidity and lead to millions of lost days at work, school and university each year. Hand disinfection is acknowledged as key element for infection control, but its effect in open, work place settings is unclear.
\end{abstract}

Methods: Our study involved a prospective, controlled, intervention-control group design to assess the epidemiological and economical impact of alcohol-based hand disinfectants use at work place. Volunteers in public administrations in the municipality of the city of Greifswald were randomized in two groups. Participants in the intervention group were provided with alcoholic hand disinfection, the control group was unchanged. Respiratory and gastrointestinal symptoms and days of work were recorded based on a monthly questionnaire over one year. On the whole, 1230 person months were evaluated.

Results: Hand disinfection reduced the number of episodes of illness for the majority of the registered symptoms. This effect became statistically significant for common cold ( $O R=0.35[0.17-0.71], p=0.003)$, fever $(O R=0.38$ [0.14-0.99], $p=0.035)$ and coughing $(O R=0.45[0.22-0.91], p=0.02)$. Participants in the intervention group reported less days ill for most symptoms assessed, e.g. colds ( 2.07 vs. $2.78 \%, p=0.008)$, fever ( 0.25 vs. $0.31 \%, p=$ 0.037 ) and cough (1.85 vs. 2.00\%, $p=0.024)$. For diarrhoea, the odds ratio for being absent became statistically significant too (0.11 (Cl $0.01-0.93)$.

Conclusion: Hand disinfection can easily be introduced and maintained outside clinical settings as part of the daily hand hygiene. Therefore it appears as an interesting, cost-efficient method within the scope of company health support programmes.

Trial registration number: ISRCTN: ISRCTN96340690

\section{Background}

Absenteeism and reduced productivity due to communicable illness, in particular acute infectious respiratory and gastrointestinal disease, are a major problem for national economies worldwide [1-5]. But because acute

\footnotetext{
* Correspondence: nhuebner@uni-greifswald.de

'Institute of Hygiene and Environmental Medicine, Walter-Rathenau-Straße 49 A 17487 Greifswald, Germany

Full list of author information is available at the end of the article
}

upper respiratory infections ("common cold") or mild cases of infectious gastrointestinal illness have a very low mortality, are in most cases short timed and self limiting they are assumed to be less costly per case than chronic conditions. Therefore, their economical impact is often underestimated and they are normally not in the focus of surveillance systems. However, large community studies in Europe and in USA have shown that communicable diseases have a great impact on 
morbidity and lead to millions of lost days at work, school and university each year [6]. Fendrick et al., for example, estimated the total economic impact of noninfluenza-related viral respiratory tract infections in the USA with $\$ 40$ billion annually. Due to their high prevalence in working-age groups they have the potential to cause substantial health-related productivity losses [7]. This results not only in missed work time and caregiver absenteeism, but in high on-the-job productivity loss due to impaired work performance, too [7]. It has been shown that acute upper respiratory illnesses can reduce one's effectiveness at work, including subjective alertness and psychomotor [5,8-15]. Economical investigations have proven that besides direct illness costs, indirect costs due to missed work time (absenteeism), caregiver absenteeism and on-the-job productivity loss, accounts for the biggest part of expenses caused by acute communicable illness [7].

While no specific protection exists against these diseases, personal hygiene, especially hand hygiene, has been acknowledged as a key element to prevent the spread in the community [16]. The efficacy of hand disinfection in medical facilities has been demonstrated a number of times [17-24]. Studies assessing the effect of the implementation of hand-hygiene regiments in nonclinical settings such as children day cares, school and university campuses or military training camps have also shown significant reductions in communicable illness and absenteeism rates [25-28]. The effectiveness of hand disinfection in open community work place settings like a public administration however has not been assessed so far. Our study provides an initial investigation of the impact of alcohol-based hand disinfectant use at work place by assessing illness rates due to common cold and diarrhoea. We furthermore estimate the economic benefits to be expected by further application of hand disinfection at work.

\section{Methods}

\section{Enrolment of participants and data collection}

This study involved a prospective, controlled, randomized design. We recruited employees from the administration of the Ernst-Moritz-Arndt University Greifswald, the municipality of Greifswald and the state of Mecklenburg-Pomerania, for the study. All administrative officers, who do not already apply hand disinfection at work, were considered for participation and got invited by e-mail or mail $(\mathrm{n}=850) .134$ persons declared their written consent to participate and completed a pre-study survey with demographic, social, health and work related questions to provide data for randomization. Participants were randomized in control $(n=67)$ and intervention $(n=67)$ group based on the frequency of customer contact and work with paper

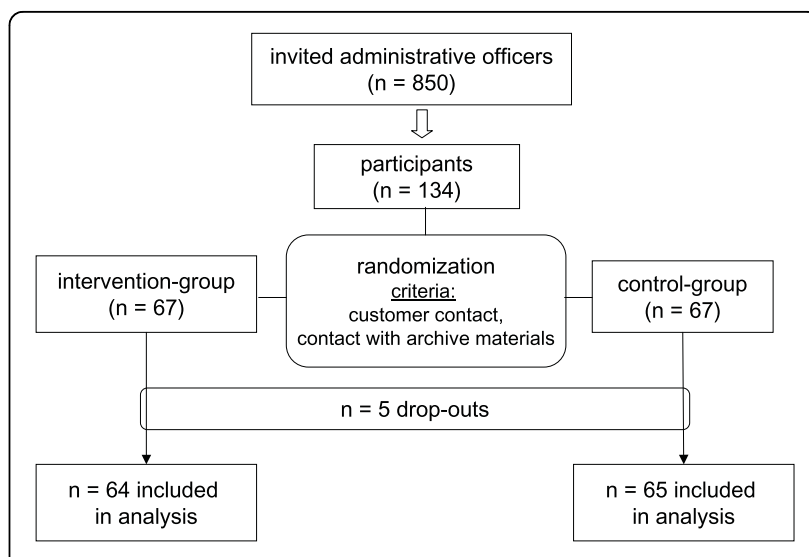

Figure 1 Flow chart showing randomization of participants.

documents, especially archive materials (Figure 1, Table 1 ). Based on the existing literature, we hypothesised, that these factors have the most relevant impact on the transmission of pathogenic organisms in administrations and therefore set as covariates [29-40]. Employees that already used hand disinfectants at work were excluded from the study.

Two alcohol based hand rubs were used in this study: Amphisept $\mathrm{E}^{\oplus}$ (Bode Chemie, Hamburg, Germany) is an ethanol $(80 \% \mathrm{w} / \mathrm{w})$ based formula and has antibacterial, antifungal and limited virus inactivating activity. Participants facing skin problems (increased dryness, redness, itching, reported by participants) were provided with Sterillium ${ }^{\circ}$ (Bode Chemie, Hamburg, Germany) which is based on 2-propanol (45\% w/w), 1-propanol (30\% w/w) and mecetronium etilsulfate $(0.2 \% \mathrm{w} / \mathrm{w})$, is known to have a refatting effect and has activity against bacteria, fungi and enveloped viruses [41-43]. Both products fulfil the requirements of the DIN EN 12791 (surgical hand disinfection) and DIN EN 1500 (hygienic hand disinfection) and can therefore be seen as equally effective $[44,45]$. Rubs were provided in $500 \mathrm{ml}$ bottles for desktop use to ensure minimal effort for use. For skin care, all participants in the intervention group were provided with hand cream care Baktolan ${ }^{\circ}$ balm, water-in-oilemulsion with no non-antibacterial properties (Bode Chemie, Hamburg, Germany).

Participants in the intervention group were instructed to use as much product as needed for complete wetting of the hands (at least $3 \mathrm{ml}$ or a palmful) of hand rub to ensure in accordance with the DIN EN 1500 (standard procedure) and advised to use it at least five times daily, especially after toilet use, blowing nose, before eating and after contact with ill colleagues, customers, and archive material [44].

Participants were provided with hand rub as needed and instructed to use the hand rub only at work, while hand hygiene at home was not changed. 
Table 1 Randomisation and distribution of evaluable participants to groups (total(control/intervention))

\begin{tabular}{lllll}
\hline Customer contact work with archive material & frequently & occasionally & Seldom or never & $\boldsymbol{\Sigma}$ \\
\hline Daily & $24(11 / 13)$ & $20(10 / 10)$ & $16(7 / 9)$ & $60(28 / 32)$ \\
\hline seldom or never & $35(19 / 16)$ & $22(11 / 11)$ & $12(7 / 5)$ & $69(37 / 32)$ \\
\hline$\Sigma$ & $59(30 / 29)$ & $42(21 / 21)$ & $28(14 / 14)$ & $129(65 / 64)$ \\
\hline
\end{tabular}

Hand hygiene remained unchanged in the control group. During the study, close contact was maintained with all participants. This included individual contact (at least monthly) either personally or by phone or e-mail. All participants were provided with contact details and could contact the study management at any time.

The study was started in March 2005 and lasted until April 2006. Surveys were sent to participants of both groups collecting data on illness symptoms (common cold, sinusitis, sore throat, fever, cough, bronchitis, pneumonia, influenza, diarrhoea) and associated absenteeism at the end of every month. Definitions of symptoms were given to the participants as part of the individual information at the beginning of the study. While most symptoms are quite self-explanatory, "influenza" and "pneumonia" are specific diagnoses that were asked state when confirmed by professional dia-gnosis only. Similarly, (self-)diagnosis of "fever" required objective measurement with a thermometer. Furthermore, compliance with hand hygiene measures was queried $[46,47]$. Test persons reported illness (ill but not absent) and absenteeism (absent from work due to illness) days per month separately for each symptom. Appearance of at least one day ill was counted as an illness episode for the current month. There was no distinction made between the number of episodes within a month. After 12 months, participants filled out a post-study survey to assess post-intervention compliance with hand hygiene [48]. Ethical approval for the study was obtained from the ethics committee of the University of Greifswald, Germany (Reg. No.: BB 02/10) and registered with the ISRCTN-register (Reg. No.: ISRCTN96340690.

\section{Statistical analysis}

All data from surveys was collected in a database (Microsoft Access 2003, Microsoft Corporation, Redmond, WA, USA) and analysed in SPSS 15 (SPSS Chicago Inc.).

To analyse the number of independent episodes of illness or absence, the number of months with and without symptoms or absence was determined, respectively. The odds ratio (OR) and confidence intervals between the two groups were then calculated and the $\mathrm{X}^{2}$ - Test used to detect statistically significant differences between groups (significance level $\mathrm{p}=0.05$ ).

To test for statistically significant differences in the total number of days absent or ill data were analysed using multivariate tests. Because data were shown to break the assumptions for parametric procedures, univariate and multivariate analysis of variance (ANOVA/ MANOVA) or covariance (ANCOVA/MANCOVA) were not applicable. Therefore we used the non-parametric approach of Puri and Sen's L-statistic to analyse data $[49,50]$. Frankly, the L-statistic, as other non-parametric test like the Wilcoxon-test, first changes data in each variable to ranks by assigning the rank of 1 to the lowest (or highest score) 2 to the next and so on up to the number of participants. Thereafter uni- or multivariate tests are performed using the ranked data. From the tests summary table, $\mathrm{r}^{2}$ as the proportion of true variance $\left(\mathrm{SS}_{\text {regression }} / \mathrm{SS}_{\text {total }}\right)$ is calculated and used to calculate $\mathrm{L}$ using the Equation ( $\mathrm{N}=$ number of participants):

$$
L=(N-1) * r \dagger
$$

The L-statistic is then compared to $\mathrm{X}^{2}$ with pqdegrees of freedom ( $p=$ number of independent variables, $\mathrm{q}=$ number of dependent variables). This method is robust against violations of the described assumptions and has been shown to be superior to its parametric pendants in terms of power and type one error, when assumptions are broken [51].

At first, a non-parametric MANCOVA using the LStatistic was used to test for global differences for all symptoms and associated days absent as omnibus test. Special effects were then determined using non-parametric ANCOVA. Differences in the number of days absent were only assessed if differences for the associated days ill were significant [52].

\section{Results}

From 850 employees asked to participate, 134 could be included in the study and data from 129 participants (64 in the intervention and 65 in the control group) were finally analyzable. During the trial, 10 participants (15.6\%) switched from Amphisept E to Sterillium.

Persons $(n=5)$ who did not return at least one evaluable survey were excluded from the analysis. Every returned survey was counted as one person month. Overall, datasets of 1230 person months $(79.46 \%$ of total possible follow-up surveys) were collected.

Compliance with hand hygiene was high during the study. Mean hand disinfection frequency reported was more than 5 times daily in 19\%, 3-5 times daily in 
Table 2 Baseline demographic data of evaluable participants

\begin{tabular}{|c|c|c|c|c|}
\hline criteria & & intervention group $(n=64)$ & control group $(n=65)$ & $p=$ \\
\hline \multirow[t]{2}{*}{ sex } & female & 60 & 51 & 0.012 \\
\hline & male & 4 & 14 & \\
\hline mean age & & 43.6 & 45.6 & 0.257 \\
\hline \multirow[t]{5}{*}{ size of household } & 1-person & 7 & 9 & 0.561 \\
\hline & 2 -person & 24 & 25 & \\
\hline & 3-person & 19 & 12 & \\
\hline & 4-person & 11 & 14 & \\
\hline & $5(+)$-person & 3 & 5 & \\
\hline \multirow[t]{4}{*}{ number of children ( $<16$ years) } & no children & 46 & 51 & 0.140 \\
\hline & 1 child & 15 & 8 & \\
\hline & 2 children & 2 & 6 & \\
\hline & 3 children & 1 & 0 & \\
\hline \multirow[t]{2}{*}{ smoker } & yes & 12 & 17 & 0.314 \\
\hline & no & 52 & 48 & \\
\hline \multirow[t]{2}{*}{ regularly participate in sport exercises } & yes & 32 & 40 & 0.187 \\
\hline & no & 32 & 25 & \\
\hline \multirow[t]{4}{*}{ means of transportation to work } & walking & 10 & 7 & 0.830 \\
\hline & bike & 23 & 23 & \\
\hline & car & 30 & 31 & \\
\hline & others & 1 & 4 & \\
\hline
\end{tabular}

$59.8 \%$, and $1-2$ times daily in $20.5 \%$ of the person month. In only $0.7 \%$ of person month an average frequency of hand disinfection lower than 1 per day was reported. There was no statistically significant change in compliance during the study $\left(\mathrm{X}^{2}\right.$-test, $\left.\mathrm{p}=0,387\right)[46,47]$.

\section{Data from pre-study survey}

Randomization in both groups was based on frequency of customer contact and contact with archive materials. According to the pre-study survey, participants were allocated to one of six groups, which were then randomly split by half into control and intervention group and as equally as possible (table 1). From all participants
$45.7 \%$ declared to have customer contact frequently and $46.5 \%$ to have contact to archive materials daily

There were no significant differences in the mean age, size of household, number of children, smoking, exercise frequency or means of transportation to work. (table 2). The difference in the distribution of women and men between the groups was unintentional.

\section{Effect on the number of single episodes of illness or} absence

Odds for being (ever) ill or absent and odds ratios (OR) between groups are presented in table 3 and 4. Frankly, hand disinfection lowered the odds to get ill with the

Table 3 Odds and OR for being ill

\begin{tabular}{|c|c|c|c|c|c|c|c|}
\hline \multirow[t]{2}{*}{ Symptom } & \multicolumn{3}{|c|}{ Control } & \multicolumn{3}{|c|}{ Intervention } & \multirow[t]{2}{*}{ OR $( \pm 95 \% \mathrm{Cl})$} \\
\hline & no & yes & odds & no & yes & odds & \\
\hline common cold & 21 & 44 & 2.10 & 37 & 27 & 0.73 & $0.35(0.17-0.71)^{*}$ \\
\hline Sinusitis & 61 & 4 & 0.07 & 57 & 7 & 0.12 & $1.87(0.52-6.74)$ \\
\hline sore throat & 31 & 34 & 1.10 & 38 & 26 & 0.68 & $0.62(0.31-1.25)$ \\
\hline Fever & 49 & 16 & 0.33 & 57 & 7 & 0.12 & $0.38(0.14-0.99)^{*}$ \\
\hline Coughing & 30 & 35 & 1.17 & 42 & 22 & 0.52 & $0.45(0.22-0.91)^{*}$ \\
\hline Bronchitis & 60 & 5 & 0.08 & 55 & 9 & 0.16 & $1.96(0.62-6.22)$ \\
\hline Pneumonia & 62 & 3 & 0.05 & 61 & 3 & 0.05 & $0.96(0.96-1.01)$ \\
\hline Influenza & 62 & 3 & 0.05 & 61 & 3 & 0.05 & $1.02(0.20-5.23)$ \\
\hline Diarrhoea & 50 & 15 & 0.30 & 56 & 8 & 0.14 & $0.48(0.19-1.22)$ \\
\hline
\end{tabular}


Table 4 Odds and OR for being absent

\begin{tabular}{|c|c|c|c|c|c|c|c|}
\hline \multirow[t]{2}{*}{ Symptom } & \multicolumn{3}{|c|}{ Control } & \multicolumn{3}{|c|}{ Intervention } & \multirow[t]{2}{*}{ OR $( \pm 95 \% \mathrm{Cl})$} \\
\hline & no & yes & odds & no & yes & odds & \\
\hline common cold & 46 & 19 & 0.41 & 53 & 11 & 0.21 & $0.50(0.22-1.17)$ \\
\hline sinusitis & 63 & 2 & 0.03 & 58 & 6 & 0.10 & $3.26(0.63-16.79)$ \\
\hline sore throat & 52 & 13 & 0.25 & 52 & 12 & 0.23 & $0.92(0.39-2.21)$ \\
\hline fever & 55 & 10 & 0.18 & 58 & 6 & 0.10 & $0.57(0.19-1.67)$ \\
\hline coughing & 51 & 14 & 0.27 & 52 & 12 & 0.23 & $0.84(0.36-1.99)$ \\
\hline bronchitis & 63 & 2 & 0.03 & 55 & 9 & 0.16 & $5.16(1.07-24.88)^{*}$ \\
\hline pneumonia & 64 & 1 & 0.02 & 64 & 0 & 0.00 & $0.985(0.96-1.02)$ \\
\hline influenza & 62 & 3 & 0.05 & 61 & 3 & 0.05 & $1.02(0.20-5.23)$ \\
\hline diarrhoea & 57 & 8 & 0.14 & 63 & 1 & 0.02 & $0.11(0.01-0.93)^{*}$ \\
\hline
\end{tabular}

*statistically significant result $\left(X^{2}\right.$-Test, $\left.p<0.05\right)$

exception of sinusitis and bronchitis. This effect became statistically significant for common cold (OR $=0.35[ \pm 95 \%$ Confidence Interval (CI):0.17 - 0.71], p = 0.003), fever (OR $=0.38$ [CI: $0.14-0.99], \mathrm{p}=0.035)$ and coughing $(\mathrm{OR}=$ 0.45 [CI: $0.22-0.91], \mathrm{p}=0.02$ ). For absenteeism, this trend continued, with the addition that the difference became statistically significant for diarrhoea too $(\mathrm{OR}=$ 0.11 [CI: $0.01-0.93$ ], $\mathrm{p}=0.017$ ). As in table 3, a difference favouring the control group was seen for bronchitis, but confidence intervals touched an OR of 1 (Table 4).

\section{Effect on the total number of days absent or ill}

Nonparametric analysis of co-variance revealed a significant difference in days ill between groups (MANCOVA, $\mathrm{p}=0.01)$. Significantly fewer days with symptoms of colds, fever and cough were reported by the intervention group. The strongest effect was identified for colds $(\mathrm{p}=$ $0.008)$. Detailed $\mathrm{X}^{2}$-test statistics, degrees of freedom and $\mathrm{p}$-values are presented in Table 5.

For colds, fever and cough a follow-up analysis of days absent was performed. While there was a trend in

\section{Table 5 Percentage of days ill and Test statistics for MANCOVA}

\begin{tabular}{cccccc}
\hline symptom & control intervention & difference & $\begin{array}{c}\mathbf{X}^{2} \text {-test } \\
\text { statistics }\end{array}$ & $\begin{array}{c}\mathbf{p}- \\
\text { values }\end{array}$ \\
\hline $\begin{array}{c}\text { common } \\
\text { cold }\end{array}$ & 2.78 & 2.07 & -0.71 & 7.040 & $0.008^{*}$ \\
\hline sinusitis & 0.12 & 0.34 & +0.22 & 1.024 & 0.312 \\
\hline sore throat & 1.53 & 1.34 & -0.19 & 0.640 & 0.424 \\
\hline fever & 0.31 & 0.25 & -0.05 & 4.352 & $0.037^{*}$ \\
\hline cough & 2.00 & 1.85 & -0.14 & 5.120 & $0.024^{*}$ \\
\hline bronchitis & 0.20 & 0.39 & +0.19 & 1.408 & 0.235 \\
\hline pneumonia & 0.08 & 0.00 & -0.08 & 1.152 & 0.283 \\
\hline influenza & 0.12 & 0.13 & -0.01 & 0.000 & 1.000 \\
\hline diarrhoea & 0.92 & 0.11 & -0.82 & 3.200 & 0.074 \\
\hline *statistically significant result $(p<0.05)$ & & &
\end{tabular}

favour of the intervention group, the difference did not become statistically significant (Table 6).

\section{Discussion}

This study is one of the first investigations on the effectiveness of hand disinfection with alcoholic rubs in a public administration as an example of an open, nonclinical setting with working adults. Our results confirm the findings from other authors, that hand disinfection has preventive effects against acute respiratory and gastrointestinal infections [53-59]. Data were analysed under the aspects of the effect on the number of single episodes of illness or absence per year and the effect on the total number of days absent or ill.

It could be shown, that hand disinfection has a reducing influence on the number of episodes of illness for the majority of the registered symptoms, with the strongest effects for common cold, coughing, fever and diarrhoea. On average, participants of the intervention group who used alcoholic hand disinfection at their workplace declared less illness episodes and therefore more symptom-free months during the year in comparison with the control group. This confirms data from other authors that the use of hand disinfection leads to interruptions of transmission chains which results in fewer illness episodes [55,59-63].

The analysis of the total number of days ill for most symptoms over the year proved similar reducing effects

Table 6 Percentage and Test statistics for MANCOVA of days absent

\begin{tabular}{cccccc}
\hline symptom & Control & Test & Difference & $\begin{array}{c}\mathbf{X}^{2} \text {-test } \\
\text { statistics }\end{array}$ & $\begin{array}{c}\mathbf{p} \text { - } \\
\text { values }\end{array}$ \\
\hline $\begin{array}{c}\text { common } \\
\text { cold }\end{array}$ & 0.372 & 0.365 & -0.007 & 1.920 & 0.166 \\
\hline fever & 0.158 & 0.225 & +0.067 & 0.896 & 0.344 \\
\hline cough & 0.372 & 0.416 & +0.044 & 0.256 & 0.613 \\
\hline *statistically significant result $(p<0.05)$ & & &
\end{tabular}


for hand disinfection. As expected, the highest infection rates for respiratory symptoms were measured during the winter months $[64,65]$. For that reason we observed the highest reduction effects in the intervention group also during winter. In contrast, we saw no seasonal peaks in the incidence of diarrhoea and so effects of hand sanitizer use were quite similar every month. Overall, a decline of days ill could was seen for most symptoms compared to the control group.

In both analyses (days/episodes) the impact on absenteeism was lower than the effect on the total of days ill. This confirms that not every case of illness with banal diseases does necessarily lead to a sick note. Rather in spite of taking illness absenteeism, employees continue working if possible, but work performance is restricted and many times insufficient. This results in an often underestimated on-the-job productivity loss.

For office work, on-the-job productivity loss is especially difficult to assess, due to the high complexity of work and the tasks performed.

In most studies on the topic, assessments of the impact on health-related productivity loss base on questionnaires on subjective items like alertness, psychomotor functioning or reaction [66]. Taken together, these studies imply the importance of impaired productivity for understanding the indirect costs associated with these illnesses. However, it is difficult to calculate explicit illness cost with these data. Nevertheless the amount of sick notes or the number of days off work may not be taken as a sole factor for the measurement of indirect illness costs. Additionally, other aspects which are not that evident and often hardly measurable like the on-the-job productivity loss have to be strongly considered. Our results confirm that there is no fixed correlation between days ill and days absent or between missed work time and on-the-job productivity loss, respectively. Hand disinfectant use reduces primarily the number of illness days which leads to less on-the-job productivity loss and consequently to a decrease in indirect illness costs. While one would expect that hand disinfection should reduce the number of days of work likewise the days ill, our trial lacked the power to show this effect.

Our study has several limitations. Only $16 \%$ of invited persons could be included in the study. Due to this, possible effects of hand hygiene are potentially underestimated. Effects of symptoms that are relatively rare but often associated with a chronic disposition or take a longer time to heal like sinusitis or bronchitis are hard to interpret on the other hand, because a single episode can have an ordinate effect. Assessment of days ill or absent as well as single episodes was based on monthly surveys. While this approach has been used by various authors $[59,61,63]$, a more refined assessment could have revealed smaller differences. Moreover, with a more detailed questionnaire, perceiving not only the symptom but the markedness of the symptom, possible effects on productivity loss could be more precisely estimated.

Further research should be focussed on the question how on-the-job productivity losses could be assessed more clearly, allowing exact calculations on the costeffectiveness of hand hygiene programmes and on the relationship between the frequency of hand hygiene and symptoms. Still, our data supports the results from other studies, that hands play a key role in the transfer of community-acquired viral and bacterial infection.

\section{Conclusion}

We were able to demonstrate that hand disinfection can easily be introduced and maintained outside clinical settings as a part of the daily hand hygiene [46,47]. Therefore it appears as an interesting, and probably costefficient method within the scope of company health support programmes.

\section{Author details}

${ }^{1}$ Institute of Hygiene and Environmental Medicine, Walter-Rathenau-Straße 49 A 17487 Greifswald, Germany. ${ }^{2}$ Institute of Biometrics and Medical Informatics, Walther-Rathenau-Str. 4817475 Greifswald, Germany. ${ }^{3}$ Bode Chemie GmbH, Scientific Affairs, Melanchthonstrasse 27, 22525 Hamburg, Germany.

\section{Authors' contributions}

$\mathrm{NOH}$ had the idea for the study and planned and supervised the trial, analyzed and interpreted the data and drafted the manuscript. $\mathrm{CH}$ participated in the design of the study, conducted the trial, helped to analyze and interpret the data and to draft the manuscript. MW helped to analyze and interpret the data and to draft the manuscript. GK helped to draft and revise the manuscript. AK participated in the study design and coordination, and helped to interpret the data and to draft the manuscript. All authors have been involved in drafting the manuscript or revising it critically for important intellectual content and have read and approved the final manuscript.

\section{Competing interests}

The authors declare a financial competing interest: GK is employed by Bode Chemie $\mathrm{GmbH}$, Hamburg, Germany. NOH and AK received financial support for research from Bode Chemie in the past. All other authors declare no conflict of interest.

Received: 5 November 2009 Accepted: 24 August 2010 Published: 24 August 2010

\section{References}

1. Bertera R: The effects of workplace health promotion on absenteeism and employment costs in a large industrial population. American Journal of Public Health 1990, 80(9):1101-1105.

2. Keech M, Scott AJ, Ryan PJ: The impact of influenza and influenza-like illness on productivity and healthcare resource utilization in a working population. Occup-Med-(Lond) 1998, 48(2):85-90.

3. Nichol KL, D'Heilly S, Ehlinger E: Burden of upper respiratory illnesses among college and university students: 2002-2003 and 2003-2004 cohorts. Vaccine 2006, 24(44-46):6724-6725.

4. Nichol KL, Mallon KP, Mendelmann PM: Cost benefit of influenza vaccination in healthy, working adults: an economic analysis based on the results of a clinical trial of trivalent live attenuated influenza virus vaccine. Vaccine 2003, 21(17-18):2217-2207. 
5. Smith A, Brice C, Leach A, Tiley M, Williamson S: Effects of upper respiratory tract illnesses in a working population. Ergonomics 2004, 47(4):363-369.

6. Bloomfield S, Aiello A, Cookson B, O'Boyle C, Larson E: The effectiveness of hand hygiene procedures in reducing the risks of infections in home and community settings including handwashing and alcohol-based hand sanitizers. AJIC 2007, 35(10 Supplement I):S27-S64

7. Bramley TJ, Lerner D, Sarnes M: Productivity losses related to the common cold. j Occup Environ Med 2002, 44:822-829.

8. Smith $A$, Thomas $M$, Whitney $H$ : Effects of upper respiratory tract illnesses on mood and performance over the working day. Ergonomics 2000, 43(6):752-763.

9. Smith AP: Respiratory Virus Infections and Performance. Philosophical Transactions of the Royal Society of London Series B, Biological Sciences 1990, 327(1241):519-528.

10. Smith AP: A Review of the Effects of Colds and Influenza on Human Performance. Occupational Medicine 1989, 39(2):65-68, 1989; 39: 65-68.

11. Smith AP, Thomas M, Brockman P: Noise, respiratory virus infections and performance. In the proceedings of the 6 th International Congeress on Noise as a Public Health Problem. Actes Inrets 1993, 34(2):311-314.

12. Smith AP, Tyrrell DA, Al-Nakib W, Barrow PG, Higgins PG, Leekam S, Trickett S: Effects and after-effects of the common cold and influenza on human performance. Neuropsychobiology 1989, 21(2):90-93.

13. Smith AP, Tyrrell DA, Al-Nakib W, Coyle KB, Donovan CB, Higgins PG, Willman JS: Effects of experimentally induced respiratory virus infections and illness on psychomotor performance. Neuropsychobiology 1987, 18(3):144-148.

14. Smith AP, Tyrrell DA, Al-Nakib W, Coyle KB, Donovan CB, Higgins PG, Willman JS: The effects of experimentally induced respiratory virus infections on performance. Psychol Med 1988, 18(1):65-71.

15. Smith AP, Tyrrell DA, Coyle KB, Williams LA: Selective effects of mior illnesses on human performace. British Journal of Psychology 1987, 78:183-188.

16. Aiello AE, Coulborn RM, Perez V, Larson EL: Effect of hand hygiene on infectious disease risk in the community setting: a meta-analysis. Am J Public Health 2008, 98(8):1372-1381.

17. Hilburn J, Hammond BS, Fendler EJ, Groziak PA: Use of alcohol hand sanitizer as an infection control strategy in an acute care facility. Am J Infect Control 2003, 31(2):109-116.

18. Johnson PD, Martin R, Burrell LJ, Grabsch EA, Kirsa SW, O'Keeffe J, Mayall BC, Edmonds D, Barr W, Bolger C, et al: Efficacy of an alcohol/chlorhexidine hand hygiene program in a hospital with high rates of nosocomial methicillin-resistant Staphylococcus aureus (MRSA) infection. Med J Aust 2005, 183(10):509-514.

19. Pittet D, Hugonnet S, Harbarth S, Mourouga P, Sauvan V, Touveneau S, Perneger TV: Effectiveness of a hospital-wide programme to improve compliance with hand hygiene. Infection Control Programme. Lancet 2000, 356(9238):1307-1312

20. Larson EL, Early E, Cloonan P, Sugrue S, Parides M: An organizational climate intervention associated with increased handwashing and decreased nosocomial infections. Behav Med 2000, 26(1):14-22

21. Harrington G, Watson K, Bailey M, Land G, Borrell S, Houston L, Kehoe R, Bass P, Cockroft E, Marshall C, et al: Reduction in hospitalwide incidence of infection or colonization with methicillin-resistant Staphylococcus aureus with use of antimicrobial hand-hygiene gel and statistical process control charts. Infect Control Hosp Epidemiol 2007, 28(7):837-844.

22. Kampf G, Kramer A: Epidemiologic background of hand hygiene and evaluation of the most important agents for scrubs and rubs. Clin Microbiol Rev 2004, 17(4):863-893, table of contents.

23. Best M, Neuhauser D: Ignaz Semmelweis and the birth of infection control. Qual Saf Health Care 2004, 13(3):233-234.

24. Neuhauser D: Florence Nightingale gets no respect: as a statistician that is. Qual Saf Health Care 2003, 12(4):317.

25. Ladegaard MB, Stage $V$ : [Hand-hygiene and sickness among small children attending day care centers. An intervention study]. Ugeskr Laeger 1999, 161(31):4396-4400.

26. Monsma M, Day R, St Arnaud S: Handwashing makes a difference. J Sch Health 1992, 62(3):109-111.

27. Roberts $L$, Smith W, Jorm L, Patel M, Douglas RM, McGilchrist C: Effect of infection control measures on the frequency of upper respiratory infection in child care: a randomized, controlled trial. Pediatrics 2000, 105(4 Pt 1):738-742

28. Ryan $\mathrm{M}$, Christian $\mathrm{R}$, Wohlrabe J: Handwashing and respiratory ilness among young adults in military training. Am-J-Prev-Med 2001, 21(2):79-83.

29. Erkältungskrankheit - Ein Lehrbuch für die Praxis. Stuttgart: Tyrell D.A.J. 1996.

30. Abad FX, Pinto RM, Bosch A: Survival of enteric viruses on environmental fomites. Appl Environ Microbiol 1994, 60(10):3704-3710.

31. Ansari SA, Sattar SA, Springthorpe VS, Wells GA, Tostowaryk W: Rotavirus survival on human hands and transfer of infectious virus to animate and nonporous inanimate surfaces. J Clin Microbiol 1988, 26(8):1513-1518.

32. Ansari SA, Springthorpe VS, Sattar SA, Rivard S, Rahman M: Potential role of hands in the spread of respiratory viral infections: studies with human parainfluenza virus 3 and rhinovirus 14. J Clin Microbiol 1991, 29(10):2115-2119.

33. Brouwer $\mathrm{DH}$, Kroese $\mathrm{R}$, Van Hemmen JJ: Transfer of contaminants from surface to hands: experimental assessment of linearity of the exposure process, adherence to the skin, and area exposed during fixed pressure and repeated contact with surfaces contaminated with a powder. Appl Occup Environ Hyg 1999, 14(4):231-239.

34. Dick EC, Hossain SU, Mink KA, Meschievitz CK, Schultz SB, Raynor WJ, Inhorn SL: Interruption of transmission of rhinovirus colds among human volunteers using virucidal paper handkerchiefs. J Infect Dis 1986, 153(2):352-356.

35. El-Dars FM, Hassan WM: A preliminary bacterial study of Egyptian paper money. Int J Environ Health Res 2005, 15(3):235-239.

36. Gwaltney JM Jr, Hendley JO: Transmission of experimental rhinovirus infection by contaminated surfaces. Am J Epidemiol 1982, 116(5):828-833.

37. Gwaltney JM Jr, Moskalski PB, Hendley JO: Interruption of experimental rhinovirus transmission. J Infect Dis 1980, 142(6):811-815

38. Khin Nwe O, Phyu Phyu W, Aung Myo H, Aye T: Contamination of currency notes with enteric bacterial pathogens. J Diarrhoeal Dis Res 1989, 7(3-4):92-94.

39. Reed SE: An investigation of the possible transmission of Rhinovirus colds through indirect contact. J Hyg (Lond) 1975, 75(2):249-258.

40. Kramer A, Schwebke I, Kampf G: How long do nosocomial pathogens persist on inanimate surfaces? A systematic review. BMC Infect Dis 2006 6:130.

41. Desinfektionsmittelliste des Verbunds für Angewandte Hygiene (VAH). mhp-Verlag 2006, Stand.

42. Anonymous: Hygienische Händedesinfektion: Indikationen, Wirkungsspektrum, Einreibemethode und Verträglichkeit: Informationsbroschüre. Hamburg: Bode Chemie 2004

43. Kramer A, Bernig T, Kampf G: Clinical double-blind trial on the dermal tolerance and user acceptability of six alcohol-based hand disinfectants for hygienic hand disinfection. J Hosp Infect 2002, 51(2):114-120.

44. DIN EN 1500: Chemische Desinfektionsmittel und Antiseptika, Hygienische Händedesinfektion, Prüfverfahren und Anforderungen (Phase 2/Stufe 2). Brüssel: CEN, European Comittee for Standardization 1997, 1-20.

45. DIN EN 12791: Chemische Desinfektionsmittel und Antiseptika, Chirugische Händedesinfektionsmittel - Prüfverfahren und Anforderungen (Phase 2/Stufe 2). Brüssel: CEN, European Comittee for Standardization 2005, 1-31.

46. Hübner C, Hübner N, Kramer A: Händehygiene in der Community. In 9 Internationaler Kongress der Deutschen Gesellschaft für Krankenhaushygiene eV. Edited by: DGKH. Berlin: Hyg Med; 2008:

47. Hübner C: Einfluss der Händehygiene in Verwaltungen auf das Infektionsgeschehen: Wirksamkeitsanalyse der alkoholischen Händedesinfektion auf Erkrankungsrate und Arbeitsleistung am Beispiel von Erkältungs- und Durchfallerkrankungen. Saarbrücken: Südwestdeutscher Verlag für Hochschulschriften 2009.

48. Hübner $\mathrm{C}$, Hübner NO, kramer A: Compliance bei der Handhygiene in einem öffentlichen Verwaltung vor, während und nach einer 12 monatigen Intervention. GMS 2009, in review.

49. Puri M, PK S: A class rank order test for a general linear hypothesis. Annals of Mathematical Statistic 1969, 40:1325-1343.

50. Puri M, PK S: Nonparametric methods in general linear models. New York: Wiley 1985.

51. Pavur R, Nath R: Power and Type I Error Rates for Rank-Score MANOVA Techniques. Multivariate Behavioral Research 1989, 24(4):477-501. 
52. Thomas JR, Nelson JK, Thomas KT: A generalized rank-order method for nonparametric analysis of data from exercise science: A tutorial. Research Quarterly for Exercise and Sport 1999, 70(1):11-23.

53. Dyer DL, Shinder A, Shinder F: Alcohol-free instant hand sanitizer reduces elementary school illness absenteeism. Fam Med 2000, 32(9):633-638.

54. Guinan M, McGuckin M, Ali Y: The effect of a comprehensive handwashing program on absenteeism in elementary schools. Am J Infect Control 2002, 30(4):217-220

55. Sandora TJ, Taveras E, Shih M, Resnick E, Lee GM, Ross-Degnan D, Goldmann DA: A randomized, controlles trial of a multifaceted intervention including alcohol-based hand sanitizer and hand-hygiene education to reduce illness transmission in the home. pediatrics 2005, 116(9):587-594.

56. Van Camp RO, Ortega HJ Jr: Hand sanitizer and rates of acute illness in military aviation personnel. Aviat Space Environ Med 2007, 78(2):140-142.

57. Vessey JA, Sherwood JJ, Warner D, Clark D: Comparing hand washing to hand sanitizers in reducing elementary school students' absenteeism. Pediatr Nurs 2007, 33(4):368-372.

58. White C, Kolble R, Carlson R, Lipson N: The impact of a health compain on hand hygiene and upper respiratory illness among college students living in residence halls. Journal of American College Health 2005, 43(5):175-181.

59. White C, Kolble R, Carlson R, Lipson N, Dolan M, Ali Y, Cline M: The effect of hand hygiene on illness rate among students in university residence hall. Am-J-Infect-Control 2003, 31(6):364-370.

60. Hammond B, Ali Y, Fendler E, Dolan M, Donovan S: Effect of hand sanitizer use on elementary school absenteeism. Am J Infect Control 2000, 28(5):340-346.

61. Lee GM, Salomon JA, Friedman JF, Hibberd PL, Ross-Degnan D, Zasloff E, Bediako S, Goldmann DA: Illness transmission in the home: a possible role for alcohol-based hand gels. Pediatrics 2005, 115(4):852-860.

62. Thompson K: The Effect of Alcohol Hand Sanitizer on Elementary School Absence. 2004.

63. White CG, Shinder FS, Shinder AL, Dyer DL: Reduction of illness absenteeism in elementary schools using an alcohol-free instant hand sanitizer. J Sch Nurs 2001, 17(5):258-265.

64. Seifart C: Banale Atemwegsinfektionen symptomatisch behandeln. Pharmazeutische Zeitung 2007, 152(42):16-26.

65. Tyrell DAJ: Erkältungskrankheit - Ein Lehrbuch für die Praxis. Stuttgart: Fischer 1996.

66. Kumar RN, Hass SL, Li JZ, Nickens DJ, Daenzer CL, Wathen LK: Validation of the Health-Related Productivity Questionnaire Diary (HRPQ-D) on a sample of patients with infectious mononucleosis: results from a phase 1 multicenter clinical trial. J Occup Environ Med 2003, 45(8):899-907.

\section{Pre-publication history}

The pre-publication history for this paper can be accessed here: http://www.biomedcentral.com/1471-2334/10/250/prepub

doi:10.1186/1471-2334-10-250

Cite this article as: Hübner et al:: Effectiveness of alcohol-based hand disinfectants in a public administration: Impact on health and work performance related to acute respiratory symptoms and diarrhoea. BMC Infectious Diseases 2010 10:250.

\section{Submit your next manuscript to BioMed Central and take full advantage of:}

- Convenient online submission

- Thorough peer review

- No space constraints or color figure charges

- Immediate publication on acceptance

- Inclusion in PubMed, CAS, Scopus and Google Scholar

- Research which is freely available for redistribution

Submit your manuscript at www.biomedcentral.com/submit
Biomed Central 